\title{
FEED POISONING IN HOLESTEIN CATTLE ASSOCIATED WITH CLOSTRDIUM BOTULINUM TOXIN (TYPE - D)
}

\author{
El-Dieb, M, K, M, * \\ - Anlmal Health Research insltule (Zigazig Branch. Chemistry Departmenl)
}

\begin{abstract}
Bolullsm is a rapidly falal disease caused by a loxin of the spore forming anaerobic beclerto Closoidium bolulnum (Cl. bolulnum). The current shidy was conducled to put an acceplable prograni of inuesllgallons. ireabnents and control of an oulbreal of boluIIsm in a catlle farm. In spring 2004. an outbreak of suspecled botulism occursed in lorge pruate farm of 5000 Holestein caltle (daby callle. heifer and calves) which were distribuled th their specinc yards. The total inixed rallon of concentrates and mineral mixture are Ule feeding stuffs of the animals. corn-sllage lately used for jeeding 18 yords of dairy cattle and helfers. 3-5 days post silage feeding a disease syndrome was appeared where 295 callle and heifer become diseasech, 55 animals were died or slaughtered The important clinical shons were lack of oppetite. abdominal respisadon. recumbercy. dullness and death General congestion and petechial haemomages of intemal organ were the promlnent necropsy findings. The drinking waler, com-sllage. blood and the liver were subjected to varlous invesilgations as : bacleriological identiji. callon of pasteurella. listerla and anaerobes for all samples, silage niycoloxin (Alfatox. (n. B)). pestlcide polsoning of Dlazkon and malathion organophosphorus compounds (in all samples) and coxtc elements determination of iron, cupper, zinc and manganese (in water). The $\mathrm{Cl}$. bolulinum toxins (types $\mathrm{C}$ and $\mathrm{O}$ ) were invesigaled in all samples. Resuls indlcaled that $C L$ botulinum (type $D$ ) anaeroblc organism was isolated from st. lage. liver and abomasum content. The $\mathrm{Cl}$ bolullium toxin (lype - D) was delected from serum, abomasum. l(wer and com.sllage. 240 diseased aninals were trealed with anlitoxin (an (lserum) types $C$ and D with supportive medical and nuirtional bealments. All the remalning healthy animals were vaccinated with blvalent loxolds lvaccines) (lypes $C$ and $D$ ) of $C L$ bolulinum " could be concluded that the com sllage may be the source of botulism in calle and the all jeeding stuffs should be periodically examined for $\mathrm{Cl}$ boltulinum organisms and their toxins. and the healthy animals should be annually vaccirated agalist botullsm by blvalent loxolds ( $C$ and $D$ types) as the caltle ore sus. ceptlble $10 \mathrm{C}$ and $\mathrm{D}$ clostridium loxins.
\end{abstract}




\section{INTRODUCTJON}

Botuism is a rapidly fatal and motor paralytic disease caused by $\mathrm{Cl}$. botulinum anaeroblc organlsm (Blood et al., 1879). Clostrdia are widely spread in the ersulronment. soll. dust and water. and 120 described strains of clostridla are present. although few can cause diseases (BaIdassl, 2005).

The clinical signs of botulism are anorexja, depression and reduce in mllk production (Gray and Bulglo, 1982). weakness of hind limbs, ataxia and recumbency (Abbitt et al.. 1984). paralysis of the tongue and chest muscle and abdominal resplraton (Kelch et al, 2000), constpaUon altemating with diarthoea, oedema and apathy (Bohnel et al., 2001), profuse saltvation and sternal recumbency (Wenzel et al., 2005). dimcult galt. low rectal temperature, high pulse rate and low blopd hydrogen lon concentration (PH) (Braun et al., 2005). The differentlal diagnosis wilh bolulism in cattle included: hypocalcaemla, hypomagnesaemia, carbohydrate overload, and several coxdicoses by: mycotoxins, nitrate, organophosphates, atroplne and atropine-like alkalolds (Kelch et al., 2000).

The post mortem (necropsy) findings Include: hyperaemla of abomasal mucosa and gas filled large Intestine (Gray and Bulgin, 1982), congestion of the small inlesune (Abbltt et al., 1884). and congestion of parenchymatous organs in case of visceral botullsm (Bohnel et al,, 2001) Who hypothesized the visceral botulism as "when long lasting absorpuion of low quantitles of Cl. botulinum toxn. that it may be interferes with the neurophysiology of the intestine. Lately. Baladassl (2005) dlwded the boltulfsm Into: neurotroplc alsorders (aTecung the nervous system). enterotoxaemlas (affectng intestine and parenchymatous organs) and gas gaugrene (myonecrosis with toxaemia).

The large molecular welght ( $M$. wh.) of $\mathrm{Cl}$. botultrum toxins (types $\mathrm{B}$ and $\mathrm{C}$ ). In part, are responsible for botulism in cattle than that of the medium, or small $M$. wt. molecules, due to the more stability of large molecules of the loxdns (Kozaki and Notermans, 1980). The mouse prolection lest bicassay is used for the tentative dlagnosis of botulism loxins. where the injection of mouse by the malze extract klled the non protecied inouse by the specinc antlloxin lGray and Bugla, 1982 and Kelch et al., 2000). The ELISA technlque speclinc for type-C toxln gives posltlve result with the extract of rumen content. weakly posluve to llver extract and negative with mllk sample (Galey et al., 2000). Botullsm-D in catlle induced neutrophllic leucocytosis (all affected animals), proleinurea (most animals) and low serum Inorganic phosphorus (some animals) (Abbitt et al., 1984).

The alm the curtent study is to pul an acceptable program of Investigations. treatments and control of botulism oulbreak in catue fami according the available data (cllnjcal and necropsy 
signs. and circumstances of animal feeding and housing and laboratory results) Lo overcom such outbreaks and for easy (In the fulure) controlling and prevendng such outbreaks in calle farms.

\section{MATERLAL AND METHODS}

\section{A) Matertal aod AnLmals:}

1- Animals: 5000 heads of Holesteln cattle $(3800$ dalry callle +1200 helfer and calves for meal productioni are reared in their parucular yards of the form.

2- Ratons: LoLl mlxed ravon: of concentrales and mineral mlxlure, and com silage.

3. Bactenologjcal media and Instriments for cultivaton of aerobic and anaebroblc specles as : $5 \%$ sheep blood agar, tween AT Albumin and IIsteria selecuve agar (for LIsterla). sheep blood agar. trypose agar and brain heart infusion agar (for Pasteurella multoclda), blood agar anaetoblc cullure and chocolate agar (for Clostrilla).

4- The high perfonnance liquld chromalography (HPLC) for measuring the mycoloxln (A)alox. (n-B)).

5- Alomic absorption for deleminauon of elements (iron (Fe), cupper ( $\mathrm{CW}$, Zinc (Zn). and Manganese (Mn)l in water.

6. Anisblotes \{penicillin. streptomycln and oxytetracycllne). anUlallerglc drugs (histakel - antlhistaminic). anu-Inflammatory dugs (clmadil - non-steroldal anll-inllammatory). supporUve llquids (saline and dextrose) and vitamines (AD3E) and source of protein and phosphorus supplementauon.

7- Clostridium Botullnum, antitoxins (types $C$ and $D$ ).

\section{B) Methode :}

a. The dalry calte, and helfer of 18 yards were fed with corn silage.

b- The animals of the olher yards were led on the Lolal mixed ration (wrthout stlage).

c. Diseased cases were appeared in 6 yards three-days anter feeding with the sllage. whiere the cilnical signis are appeared in 295 animals. 55 anlmals are died and the remoining anlmals receiving different lypes of medical treatinents and supportlve trealnients before the dimnlt diagnosls. After dlagnosis of bolulism. the treatments wh the specinc antitoxn (anuserurn). The blualent vacclnes (loxolds. types $C$ and $D$ ) was given to the semained healthy asimals (Lobato et al., 1999). 
d- The clinical slgns and the necropsy findings were recorded from the diseased and died anlmals respectuvely.

e- Laboratory investigations:

The com sllage, water, blood. Liver and abomasal content were subjecled to difterent types of invesugations as follow: bacteriological examination for pathogenle bacterla (pasteurelia, and lls(erta) (Crulcbshants et al.. 1975). Mycotoxins (AFBl) In sllage and dlazinon and malathlon organophosphorus compounds (n all samples (Association of Analytical Chemists, 1980), toxdc elements (as cupper, manganese, Iron, and $Z$ Inc) in the water according to (American Public Health Association, 1971), anaerobes (Clostrldlum botulinum) in all samples (Guinn et al., 1994) and the mouse protection bloassay used for detection of toxins of Clostridium botulinurn (C and D) (Gray and Bulgin, 1982). "The Invesugated samples from died anlmals were compared wth that of normally slaughtered healthy antmals that frequently slaughtered for meat producton in the same farm.

r- Symplomalc treatments were tried by antibloucs. saline - dextrose solution, antlInflammatory. antlallerglc. vitamins (AD3E injectlon). protein and phosphorus supplementatuons. Coollng time was increased to 10 hours/day, and only two mllkings Instead of three times / 24 hours. all these irals of disease treatments were cartled out before diftnit diagnosis of the botulism.

\section{RESULTS}

A. Cllntcal Slgne of Botullsm in Cattle were : Off food, slow movements, weakness of hind limbs, recumbancy after $8 \mathrm{hrs}$ from startng the cllnical slgns, abdominal resplration. normal body temperature and putse rates, consupation, marked decrease of milk yreld, dullness. death (55 died (rom 295 total diseased anlmals), all these symptoms appeared 3-5 days post sllage reeding.

B- Post mortem (Necropsy) fladings: Gelatunous texture of the body fats, congestion of kJdneys and heart wth petechlal haemorrhages (especlally in (hear). congestion of abomasum. Ilver, intestine and lungs, and enlargement of the gall bladders.

C Laboratory examinatlons: The results of the bacterlologlal Investgatuons showed the presence of $\mathrm{Cl}$, botulinum (type-D) whlch detected in com sllage and abomasals content. The results of mouse protection bloassay is the presence of Cl.botulinum neurotoxin (typeD). 
D- The other different examined parameters (other palhogenic bacterla. Alatoxin-B). organophosphorus compounds, loxtc elements) are negauve or whin permicible limls. The results are tabulated in Lable (1).

E- Results of treatments of Botulism in Ccatte:

1. Treatment with antiserum:

a- Clostrldium bolulinum (types $C$ and $D$ ) horse-anlloxins for isealment of cattle which were suffering from botulism. as calde are susceptible to the $C$ and $D$ clostridium loxins. The anuserum was prepared and supplied by the Velennary Research Insulute IOndersteopoort. 0110. Soult Arrical.

b- The antitoxln-D (5ml) was mixed with the antitoxin- $\mathrm{C}(5 \mathrm{~m}))$ and given intravenously by sin. gle dose of $10 \mathrm{ml}$ (types $C$ and D) In the early stage of Bolullsm which was usually adequate dose, a 2nd injection (wthin 18 hours) may be needed if clear clinical iniprovement is not apparent. Further trealment with antloxin arter the 2 nd antuloxin trealment should not be Laken under any condiuon.

c- Antallerglc drug (Histakll - anthistamlnlc) and the cimadil (non-stroidal - antlInnammatory) drug were administered parallel with treatment with the antloxin (andser. um).

d. All catue suffered from botullsm (In its early slage) and treated with andioxins (C. D) showed clear Improvement, but the trealment with the antitoxin was non-effeclive in cases of the late slage of the disease.

e- Supportive (saline-dextrose) liquid therapy, vilamines AD3E. mineral mixlures lespeclally phosphons) and protein rich feed were also supplled paralled whth the antiserum.

\section{2- Vacctnation with toxoids (Botulism vaccines):}

a. Formalinized alumlnum hydroxide gel adsorbed bivalent toxolds of $\mathrm{Cl}$. botulinum (types $\mathrm{C}$ and D) used for Immunizauon of cattle againsi bolulism. the vaccine was prepared and supplied by Onderstepoor Blologlcal Products (Onderstepoort. 0110. South Africa).

b. All the healthy caltle were vaccinated with the bolulism vaccine by slerillzed syninges with. out any disinfectant. and wth a separate needle for each animal. the dose is $2 \mathrm{ml}(\mathrm{s} / \mathrm{c}) / \mathrm{an}$. Imal. The vacclne will prolect the animals againsi the bolulinum toxin.

c. The vaccination wh the loxolds were carnted out twicely (4.7 weeks apart), then aner, the vaccination of all herd will carred out (only one (njecuoi) annually). All vaccinated animals 
may led the contaminated sllage with botulloum toxins without appearance of any clinical signs of botullsm.

\section{DISCUSSION}

The current study revealed that the diseased cattle in the farm showed the following clinical signs: of food, decreased movement and activity, abdominal resplration. constipation, marked decrease of milk yleld. normal temperature and hlgh pulse rate, recumbency (6-8 hrs from startIng the signs) and death (2-4 days from starting the signs). Such clinical signs of botulism were recorded by Gray aad Bulglo (1882). Abbltt et al. (1984). Kelch et al. (2000). Bohnel et al. (2001). Wenzel et al. (2005) and Braun et al. (2005).

The necropsy findings of died catte of the present sludy were congestions of the Internal organs and petechlal haemorrhages on the organs especlally on hearl. such necropsy inding could be recorded by Gray and Bulgio (1882), Abbltt et al. (1984), and Bohnel et al. (2001).

The mortallty rate In diseased catcle with botullsm was 18.6\% (55 died animals from 295 total diseased ones). A higher mortality rates could be reported by other authors, with vartous percentages may attributed to the different factors and clrcumstances, it may be $62.7 \%$ witl) toxdn. $D$ (Abbitt et al, 2984). 77.8\% despite treatments (Gray agd Bugln, 1982), 30.8\% with toxtn-D (Herdt et al, 1981) and $96.8 \%$ with type-C toxln (Galey et al., 2000).

The current Investigalion revealed presence of $\mathrm{Cl}$. botulinum loxin (type $\mathrm{D}$ ) In the com silage feed. blood, liver and abomusum content of diseased catte. Simflar study on boluism of catte due to feeding on Infected grass-sllage could be reported by Notermana et al. (1981). Cattle are usually affected by types $D$ and $C$ toxtns. Oucbreaks of botulism in cattle are most likely to occur during drought periods when feed is sparse. phosphorus intake is low and cartion is plenuful (Radostita et al., 2000). so that the anutoxns (antiserum) of types $D$ and $C$ were injected to diseased cattle in the early stage of botulism due to the susceptibility of cattle to these two types of toxins and as a precautional program. also the vaccination of heaithy cattle was achieved in the present study by the $C$ and $D$ coxolds (vaccines) agalnst both the botulinum toxins ( $C$ and D). (wo vacclnatlons $(21$ days apart), then one vacciration annually. The anubody levels must be checked two times yearly. The anubody levels agalnst botulisnum toxins were determined using the Serum Neutralization Test in mice. The monovalent vacclne Induced higher antibody lev. els than the blvalent vaccine. Vacclnation with type-D Induced higher antbody levels than that of the type-C toxold (Lobato et al., 1998), but the vaccinauon wth blvalent toxolds $(C$ and $D$ (ypes) should be practlced in enzootlc areas (Radostits et al.. 2000). 
The supportive treatment by sufnclent quanutles of (sallne-dextrose), vitamils (AD3El and phosphorus, and proteln rich feed. then the anti-Inflammatory and the anvallergic drugs are the medications used for treatment of diseased calle, along with the specinc anudote (anitoxin) as rollowed in the current study. The correction of olletary deflelencies by supplementation with phosphorus and protein should implementcd if condltions permit. Some local reacuons are en. countered afler glving toxold or anlitoxin, but they arc seldon serious, so the antaliergic and anti-Inflammatory drugs should be adminlstered along with the ancloxin therapy (Radostlts et al., 2000),

Based on the current work. It could be concluded that the corn sllage may be the source for botulism In Holesteln caulle. and this fact should put In consideration in such oulbreaks. Anls. toxun (anuserum) types $\mathrm{C}$ and $\mathrm{D}$ of $\mathrm{Cl}$. botulinum should be adminlstered in uhe early slage of botulism outbreaks. Annual vaccination of the catcle wiun blvalent vaccines fof types $C$ and $D$ \} should be one of the vaccinatlon program in catue farms wit) intermiltent checking for anubody levels against the Cl.bolulinum polypepude neuroloxins. AJso. pertodical examination of stlage. hay and other feeding stuffs and water for botulimuly toxins and other loxins should be carted out. the animal feeding stulfs should be in balanced manner and rich with phosphons and proteln to make the animals partially non-susceptuble to bolullsm. 
Tuble (1): The results of laboratory examinations of water, silage, blood, abomssal coatent and liver.

\begin{tabular}{|c|c|c|c|c|c|c|}
\hline $\begin{array}{l}\text { Exumined } \\
\text { materials }\end{array}$ & $\begin{array}{c}\text { Bacteriological } \\
\text { examination }\end{array}$ & $\begin{array}{c}\text { Aflatorin } B_{4} \\
\left(A_{F B} B_{1}\right)\end{array}$ & $\begin{array}{l}\text { Organopho- } \\
\text { spbrus cpds } \\
\text { (Diazinon } \\
\text { and } \\
\text { Malatbion) }\end{array}$ & $\begin{array}{l}\text { Toxic Elements } \\
\text { (Cupper, Iron, } \\
\text { Manganese, Zinc) }\end{array}$ & $\underset{\text { botulinum }}{a}$ & $\underset{\substack{C \\
\text { botulinum } \\
\text { toxins }}}{C}$ \\
\hline Water & N.P. & N.D & -ve & $\begin{array}{l}\mathrm{Cu}=0.33 \pm 0.063 \mathrm{ppm} \\
\mathrm{Fe}=0.22 \mathrm{~s} \pm 0.03 \mathrm{ppm} \\
\mathrm{Mn}=0.12 \pm 0.018 \mathrm{ppm} \\
\mathrm{Zn}=0.14 \pm 0.031 \mathrm{ppm}\end{array}$ & -ve & veve \\
\hline Corn silage & $\begin{array}{c}\text { Anacrobes } \\
\text { (Cl.botulinum) }\end{array}$ & $8 \pm 0,63 \mathrm{PPb}$ & .ve & N.D & $\begin{array}{c}\text { tre } \\
\text { (ope-D) }\end{array}$ & $\begin{array}{c}\text { twe } \\
(\text { oppe-D) }\end{array}$ \\
\hline Blood & N.D. & N.D & ve & ND & ve & $\begin{array}{c}\text { twe } \\
\text { (type-D) }\end{array}$ \\
\hline $\begin{array}{l}\text { Abomasal } \\
\text { content }\end{array}$ & $\begin{array}{c}\text { Anaerobes } \\
\text { (Cl botulimum) }\end{array}$ & N.D & -ve & N.D & $\begin{array}{c}\text { tve } \\
\text { (type D) }\end{array}$ & $\begin{array}{c}\text { twe } \\
\text { (oppe-D) }\end{array}$ \\
\hline Liver & $\begin{array}{c}\text { Anaerobes } \\
\text { (Clootulinum) }\end{array}$ & N.D & -ve & N.D & twe & $\begin{array}{l}+ \text { we } \\
(\text { type-D) }\end{array}$ \\
\hline
\end{tabular}

1- N.P. = aon patbogenic bacterla, 2 - ve = not present (Eeģative result),

3. + ve = present (positive result), 4- N,D. $=$ aot doas, S. permicible value of $A F B$, in fecd $=>20 \mathrm{PPb}$ 


\section{REFERENCES}

Abbltt, B.; Murphy, M. J.; Ray, A C.; Reagor, J. C.; Eugster, A R.; Gayle, L. G.; Whltford. H. W.: Sutherland, R. J.; Fyokke, R. A and Pusok, J. (1984) : Calastrophilc death losses In a dalry herd attributed to type D bolulism. Vel. Med. diagnosic Lab.. Drawer 3040, College statlon. Texas 77841 , USA.

Amertcan Public Health Agsoclatlon (APHA) (1971): Standard melhods for the examinalion of water and waslewaler. $31 \mathrm{~h}$ ed. Washington. D.C.

Associstion of Analytical Chemiats (AOAC) (1980): Ofncial melhods of analysis. 13th ed.. Washinglon D.C.. USA.

Baldarsi, L. (2005) : Closutdlal toxins: polent polsons. polent medicines. Joumal of Venomous Animals and Toxins including Iropical Diseuses: $11(4)$ ): 391.411 .

Blood. D. C.: Henderion. J. A. and Radostits. O. M. (1979) : Velerinary Medicine. a lexl book of the diseases of calde. sheep, plgs and horses. Botulism pp: 441 .

Bobacl, H.; Scbwagerlck, B. and Gessler, F. (2001) : VIsceral bolullsm. a new form of bovine Clostrddum botulinum toxcation. J. Vet. Med.. series-A. 48(5): 373-383.

Brawa. U.: Feige. K.: Scbwelzer. G. and Pospiscbl. A (2005) : Clinlcal nndings and treatment or 30 calde with bolullsni. Vet. Record. 156(14): 438.441.

Cruicbsbaok, R.; Duguld. J. P.: Manion. B. P. and Swala, R. H. A. (1975) : Medical microbial. ogy 12 th ed.. Vol. II, publlshed by Churchill Livingston. Edimburgh), London and New York.

Galey, F. D.: Tern, R.; Walker, R.; Adaska, J.: Etchebame, M. A.; Puschner, R.; Ptober, E.; Whitlock, R. H.: Rocke, T.: WWoughby, D. and Tor, E. (2000): Type C bolulism in dalry callle from feed contamlnated with a dead cal. J or Vet. Med. Dlagn. Invest.. 12(3): 204-209.

Gray. T. C. and Bulgla. M. S. (2982): Bolulism in an Oregon dairy cow herd. J. Aun. Vel. Med. Ass., 180(2): 160-162.

Herdk, P. de.; Haesebrouck, F.; Haagsma, J.: Devrlese, L. A; Dom, P. and Moens, J. (1891): An oulbreak of boune botullsm with high morbldity and mortallty. Vlaams. Diergeneeskundlg Tydschnfl; 60(6): $216-218$.

Keleb, W. J.: Kerr, L. A: Pragle, J. K.: Robrback, B. W. and Whitlock. R. H. (2000): Fatal Clostrdium bolulinum toxcosis in eleven Holstein calle fed round bale barley haylage. 
J. Vet. Dlagn. Investlg., 12(5): 453-455.

Kozaki، S. and Notermans. S. (1980) : Stabilltes of closirldum botullnum type B and C toxins in ruminal contents of caltie. Appled and envronmental microbtology, 40(1): 16) -192 .

Lobato. F. C. F.; Almelda. A. C. de.; Abreu, V. L. V. de.; sllva, N. da.; Nascimento, R. A. and Martlne. N. E. (1899): Revsta Brasileira de mediclna veterinarya. 21(1): 25-27.

Notermans, S.; Dufrenne, J. and Oosterom, J. (1981) : Persistence of Closiridlum bolullnum type $B$ on a calue farm after an outbreak of botullsm. Applted and Envronmental Microblology: $41(1): 179.183$.

gulnn, P. J.: Carter, M. E.; Markery, B. K. and Carter, G. R. (1994) : Clinical veterinary Microblology, year book, wolfe publishing Mosbly. Europe Limiled.

Radostits, O. M.; Gay, D. C.; Blood, D. C. and Hlachelif, K. W. (2000) : Veterinary medlcine "a text book of diseases of callle, sheep. pigs and horses", 9th ed.. W.B. Saunders Corr1pany Lid.

Wenzel, C.: Hallbeck, S.: Wogerle, G., Schulze, C.: Gehrlsch, B.; Weber, B. and Feldman, T. (2005) : Large outbreak of botullsm on a dalry farm wth atyplcal symptoms. PTakusche Tlerarzt, 86(4): 260-265. 


$$
\begin{aligned}
& \text { اللمتصن العويى } \\
& \text { التسـمم الغذانى فى البة الهولستين المصاحب لسم الكولستريديوم بوتيولينمب - نوع د } \\
& \text { مسحمود كمال مهطفى الديب؟ }
\end{aligned}
$$

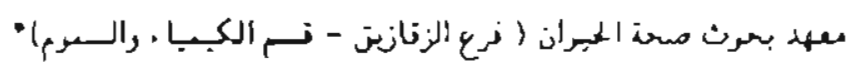

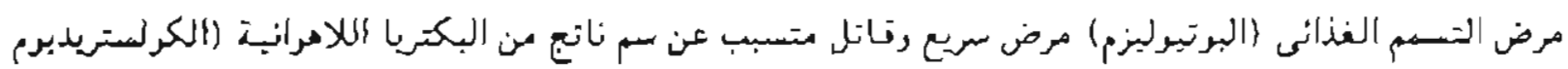

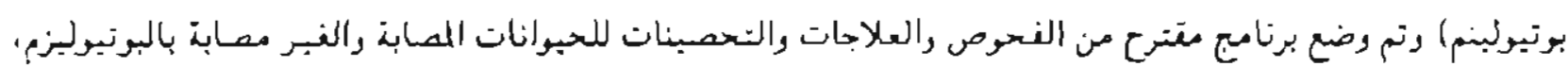

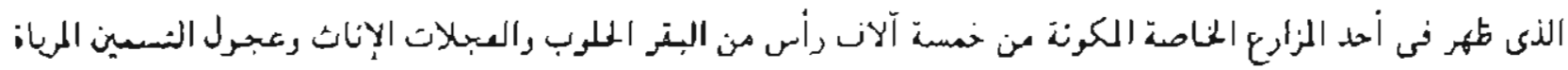

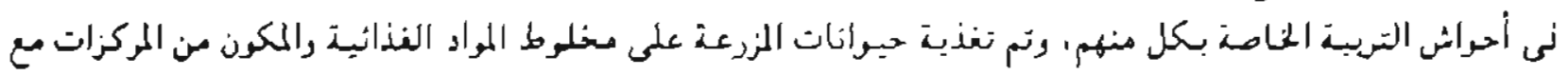

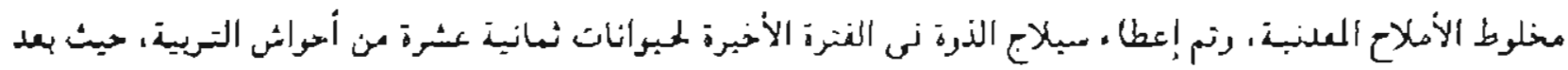

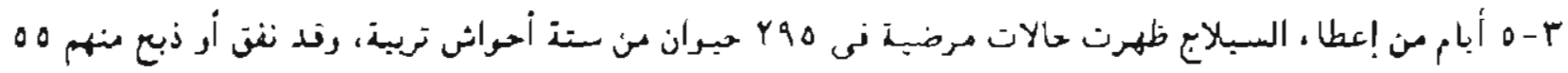

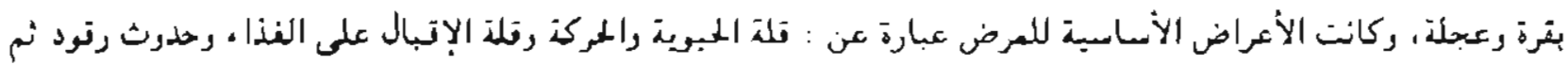

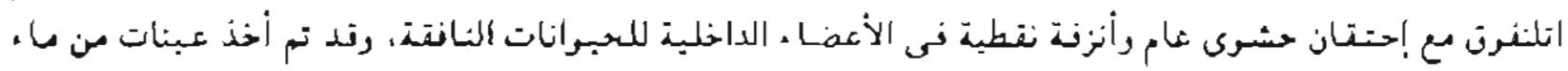

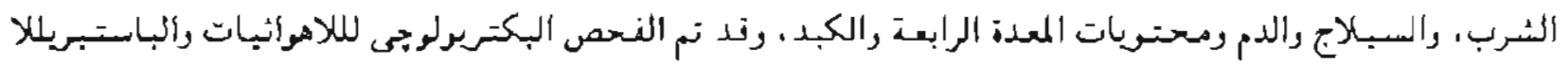

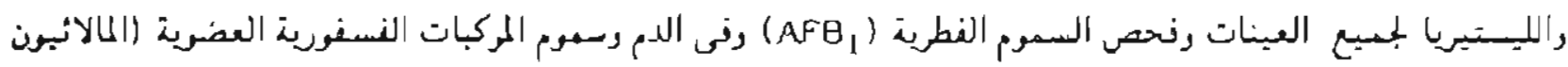

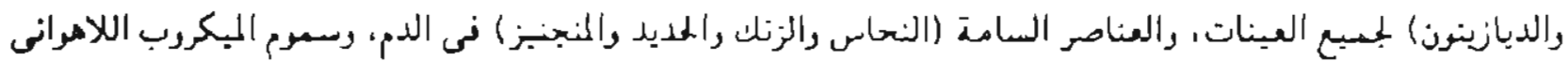

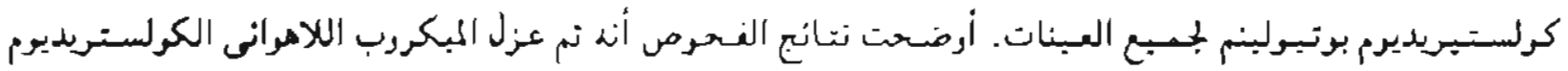

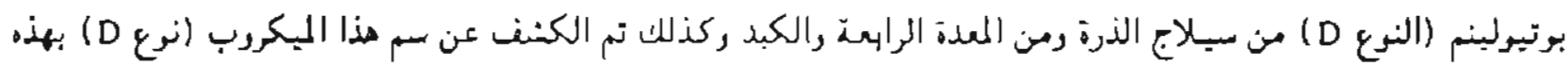
العينات أيضا رنى المبل.

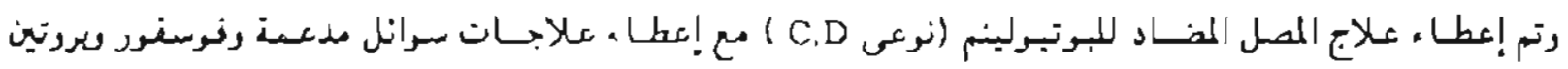

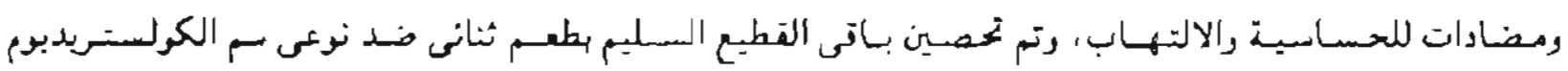
برتيولينم (C.D) (2)

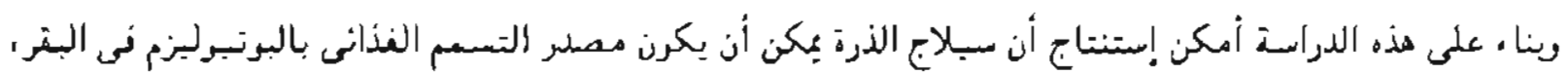

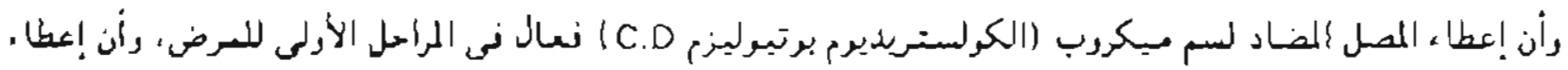

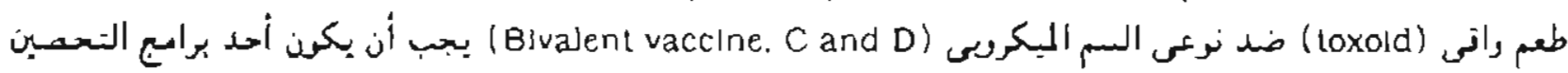

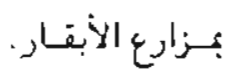

Marsoura, Vel. Med. J.

Vol. VU, No, 2, 2006 